\title{
Effect of some Technological Treatments on Physical Properties and Bioactive Components of Ripe Soft Persimmon Fruits
}

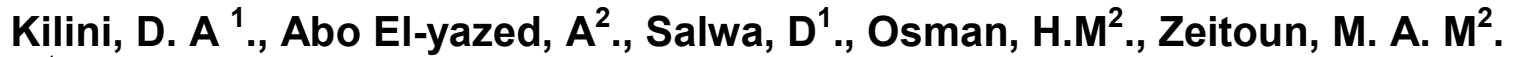 \\ ${ }^{1}$ Hot Crop Processing, Res. Dept., Food Technol. Res Inst., A.R.C, Alex. Lab., Egypt \\ ${ }^{2}$ Food Sciences Dept., Fac. of Agric., Saba Bacha, Univ. of Alexandria, Egypt
}

\begin{abstract}
Fruits of persimmon are considered as one of the health promoting foods which has been established as one of the major fruits. Persimmon is one of the fruits processed mainly by drying. Persimmon (Diospyros kaki coststa.) fruit is rich in health promoting substances. It contains health promoting bioactive compounds like, ascorbic acid, total phenolic and carotenoids, which have antioxidant properties. The objective of this investigation was to evaluate the quality of blanched and dried peel and pulp of persimmon fruits. This quality was estimated by determining of physical properties, chemical composition, some bioactive components and antioxidant activity of peel and pulp. To achieve this aims persimmon fruits were sorted and graded then washed and blanched to inhibit the enzymes during drying. Physical properties, Chemical properties and bioactive component were determined to evaluate the effect of blanching on dried persimmon peel and pulp. The obtained results showed that the $L^{*}$ (brightness) of unblanched and blanched dried pulp were 59.17 and 61.55 , respectively. The values of $a^{*}$ (redeness) and $b^{*}$ (yellowish) of unblanched dried pulp were 1.37 and 18.85 , respectively. The blanched treatment increased $a^{*}$ and $b^{*}$ values of blanched dried pulp. Therefore, the blanched treatment had a positive effect on dried persimmon. Bulk density was increased by blanching from 0.52 to $0.59 \mathrm{~g} / 100 \mathrm{ml}$, water holding capacity $(\mathrm{WHO})$ increased from 80.5 to $85.9 \mathrm{~g} / 100 \mathrm{ml}$, oil holding capacity increased from 90.6 to $96.5 \mathrm{~g} / 100 \mathrm{ml}$ and emulsifying capacity increased from 25.18 to 35.01 by blanching dried pulp. In the same time the blanching of the dried persimmon slightly increased moisture, protein, lipid, ash, carbohydrate and fiber for both pulp and peel persimmon. The decreasing rate of ascorbic acid in unblanched dried pulp was higher than blanched dried pulp (ascorbic acid was $180.3 \mathrm{mg} / 100 \mathrm{~g}$ decreased to $150.8 \mathrm{mg} / 100 \mathrm{~g}$ in unblanched dried pulp where it was $200.2 \mathrm{mg} / 100 \mathrm{~g}$ in fresh pulp). Blanching had increased total phenol, $\beta$ carotene and in the same time antioxidant activity percentage were increased in blanched dried pulp $(75 \%$, while it was $70 \%$ in unblanched dried pulp). The same trend for bioactive component was obtain for dried peel in ascorbic acid, total phenol, $\beta$ carotene and antioxidant activity.
\end{abstract}

Keywords: Persimmon, bioactive components, blanching, antioxidant activity, physical properties.

\section{INTRODUCTION}

Persimmon is one of the tropical and subtropical fruits. Persimmon was grown in the nineteenth century in Europe (Liu et al., 2007). Today the fruit is cultivated not only in Japan and Vietnam but also is planted in Brazil, Iran, Lebanon, Spain, Italy, Tunisia and Algeria. There are about 3,000 different varieties of this fruit. The fruit shape is generally round and cordite, (Hazbavi and Minaei, 2010).

Persimmon was introduced into the Mediterranean region by the end of the 19th century, first as an ornamental tree, and it was also appreciated for the quality of its wood. As a fruit tree, it was grown as isolated trees in gardens, family orchards or in small plantings, and their fruits were locally consumed. The species spreads along the Mediterranean coast, and coexists with citrus, fig and olive trees (Peracoh., 2015). 
Persimmon is fleshy fibrous tropical, deciduous fruit belonging to Ebenaceae family. It is commonly cultivated in warm regions of the world including China, Korea, Japan, Brazil, Turkey, and Italy (Itamura et al., 2005; Yokozawa et al., 2007). In 2007, the global production of persimmon reached over 3.3 million tons, with $70.0 \%$ from China, $10.0 \%$ from Korea and $7.0 \%$ from Japan. The persimmon is not so popular in European communities but its demand is increasing owing to consumer's awareness regarding its hidden health promoting potential. Mediterranean region is also suitable for persimmon production that has reached up to 110,000 tons (Jung et al., 2005; Luo, 2007; Bubba et al., 2009).

Persimmon fruit is rich in fiber and has important amount of minerals, carotenes and polyphenols (Park et al., 2008). Additionally, several studied have showed antidiabetics, antiaetrogenic and antiobesity effects of persimmon leaves and fruits (Yordanov, A. 2011).

Persimmon (Diospyros kaki L.) is the main and leading that consumed in the Egyptian market. It is not left to ripe on the trees and harvested at mature stage to ripened for commercial production and marketing (Hafez et al., 2010). Persimmon is relatively high content of dietary fibers, total and major phenolics, main minerals and trace elements make persimmon preferable for healthy (Novillo et al.,2014). It is also a good source of fiber and vitamins, mainly A and C. It is mainly eaten fresh, but can be frozen, canned or dried and can be stored for up to 6 months in modified or controlled atmospheres (Sultan et al., 2016). The dried persimmon portions could be used as ingredient in products such as snacks and breakfast cereals (Sharma et al., 2013). Most fresh fruits have a short harvest season and are sensitive to deterioration; therefore, making fruit leather from fresh fruits is an effective method to preserve fruits (Novillo et al., 2015). Fruit leathers are manufactured by dehydrating a fruit puree into a leather like sheet. Fruit leathers are often considered as a health food, therefore there are large numbers of fruit leather products available on the market.

Since, persimmon cultivars in Egypt are the non-astringent such as 'Costata' $\mathrm{CV}$. It considered one of the important cultivars, which is very easy to soften after harvesting and handling at ambient temperature (Lo'ay, 2010). Although, Egypt has a great potential to produce high fruit quality and export to other countries. Its marketability is still limited to local market. This is due to the delicate nature of fruit, poor post-harvest technique for handling and transporting and storage facilities (Özdemir et al., 2009), and the common technique for controlling fruit ripening processes under ambient temperature. Nowadays, persimmons are cultivated world widely with $90 \%$ of production being obtained in China, Japan and Korea. In Bulgaria the persimmon is one of the most recently introduced fruit-trees and probably because of this, there is only a scarce data about the chemical composition of Bulgarian persimmons (Mangarova, 2011 and Yordanov, 2011). Several environmental and genetic factors such as cultivar, harvest time, habitat, fertilization, and climate affect the accumulation of biologically active substances in the fruit and precise information for physiological activities of persimmons depend 
mainly on cultivars. Maturity stage is another factor determining the organoleptic and functional properties of the fruits. In the literature, several papers investigating the phytochemical and nutrient composition of persimmon fruit are available, but there are only few articles dealing with the changes of these parameters during the ripening process (Senter et al., 1991; Kondo et al., 2004; Salvador et al., 2007, Bubba et al., 2009). Blanching and drying are the common steps to obtain high dietary fiber powder from fruit by-products. During processing, blanching is usually performed before drying to inactivate enzymatic reactions (Larrauri, 1999). In order to obtain a nonperishable product that is easy to use, the persimmon peels can be dried and ground into powder. Indeed, persimmon peel powder could be used to enhance food products through its nutrients, dietary fibers and natural antioxidants.

Drying is one of the oldest methods of food preservation. Fruits can be dried to extend their shelf life, and this gives us the opportunity to benefit from these fruits off season. Persimmon (Diospyros kaki L.) is not marketed efficiently because it stays in the markets for a short period of time, and therefore consumers and producers cannot benefit from it adequately (Akyıldız et al., 2004).

Fresh and dried persimmons are important nutritional product, which have high content of sugars, as glucose and fructose as a source of energy. The important parameters for determination the quality of fresh and dried persimmons is content of total dry matter and moisture content, respectively. Most of the dry matter goes to simple sugars, glucose and fructose, as the most represented in persimmon fruits. According to Fennema (1977), ascorbic acid is considered as an index of nutrient quality during processing and storage of foods, and that's why we examined the content of vitamin $\mathrm{C}$ in fresh and dry.

The objective of this investigation was to evaluate the effect of blanching on the quality of dried peel and pulp of persimmon fruits. This quality was estimated by determining of physical properties, chemical composition, some bioactive components and antioxidant activity of peel and pulp.

\section{MATERIALS AND METHODS}

\section{Materials}

\section{Persimmon fruits:}

Fresh and Seedless persimmons (Diospyros kaki L., var. costata) of the same ripeness fruits were purchased (free from physical defected )from local farm Alexandria Governorate, Egypt.

\section{Chemicals:}

All chemicals used were of analytical grade, and were purchased from ELGamhouria Co. for Chemical and Medical Requisites, Alexandria, Egypt. DPPH reagent (1,1- diphenyl -2 picrylhydrazyl) was obtained from Sigma Company, Germany. 


\section{Methods:}

These methods included the preparation of pulp and its products, which were unblanched $(\mathrm{U})$, blanched with hot water $(\mathrm{BW})$, and dehydration of peel and pulp persimmon.

\section{Pretreatments:}

Seedless persimmons (Diospyros kaki L., var. costata). The fruits were randomly divided into two groups: one for use as fresh and second as dried fruits.

\section{preparation of persimmon fruit:}

Fresh persimmon fruits were subjected of the following different process:

1. Washing of persimmon (cultivar costata) in cold running tap water.

2. Blanching of persimmon in hot water $\left(90^{\circ}-95^{\circ} \mathrm{C}\right)$ for different times $(10,20,30,40,50$ and $60 \mathrm{sec})$. Then the poly phenol oxidase activity was determined for each times of blanching to choose the optimum time and temperature for complete inhibition of enzyme polyphynol oxidase enzyme (ppo).

3. Washing of persimmon by cold water immediately after blanching.

4. Control sample of persimmon dried (without blanching).

\section{Determination of enzyme activity:}

Three $\mathrm{ml}$ buffered catechol solution $(0.01 \mathrm{M}$ catechol, freshly prepared in $0.1 \mathrm{M}$ phosphate buffer, $\mathrm{pH} 6.0$ ) was add to clean cuvette of a spectrophotometer, then $1 \mathrm{ml}$ enzyme extract by Galeazzi et al. (1981) methods and $2 \mathrm{ml}$ distilled water were added in the cuvette. Enzyme unit = the change in absorbate at $495 \mathrm{~nm}$ that recorded for every $30 \mathrm{sec}$ up to $5 \mathrm{~min}$ at $25^{\circ} \mathrm{C}$.

Table (1). Effect of blanching time on activity of poly phenol oxidase

\begin{tabular}{lcccccc}
\hline & \multicolumn{5}{c}{ Activity of polyphenol oxidase (\%) } \\
\cline { 2 - 6 } Blanching in hot water $\left(\mathbf{9 0 - 9 5 ^ { 0 }} \mathbf{C}\right)$ & \multicolumn{5}{c}{ Blanching time (sec) } \\
\cline { 2 - 6 } & 10 & 20 & 30 & 40 & 50 & 60 \\
\cline { 2 - 6 } & 30.51 & 20.25 & 15.60 & 10.32 & 5.02 & 0.00 \\
\hline
\end{tabular}

Therefore, we chose blanching in hot water $\left(90-95^{\circ} \mathrm{C}\right)$ for $60 \mathrm{sec}$ which the time stopped activity of enzyme polyphenol oxidase.

preparation of persimmon peel extracts:

Persimmon fruit were washed with tap water and peeled off with peeler (a knife and sliced into about $1 \mathrm{~cm}$ size). The peels were dried until reaching a final moisture content of $3-4 \%$ then grinded with blender and sieved through a 60 mesh to obtain peel powder. A $200 \mathrm{~g}$ of peel powder were extracted in $1800 \mathrm{ml}$ of $70 \%$ ethanol solution for $24 \mathrm{~h}$. The persimmon peel extract was filtrated and concentrated by rotary evaporator. The final concentration of persimmon peel extract was adjusted to $10 \%$ and kept in freezing up to analysis. 
preparation of persimmon pulp:

Persimmon fruit were carefully washed by tap water, drained, dried with a soft cloth and cut into halves. The persimmon fruit halves were manually peeled and cut into pieces using stainless steel knives.

Table (2). Trial for choosing the best temperature for $48 \mathrm{~h}$ according the bioactive content

\begin{tabular}{cccc}
\hline \multirow{2}{*}{ Parameters } & \multicolumn{3}{c}{ Temperature } \\
\cline { 2 - 4 } & $\mathbf{5 0 ^ { \circ } \mathbf { C }}$ & $\mathbf{6 0 ^ { \circ } \mathbf { C }}$ & $\mathbf{7 0}^{\circ} \mathbf{C}$ \\
\hline Viscosity & 140.00 & 150.00 & 135.00 \\
Ascorbic acid mg/100g & 20.88 & 25.33 & 18.60 \\
Total phenol mg/100g & 220.20 & 240.35 & 215.80 \\
$\beta$ - carotene $\mathrm{mg} / 100 \mathrm{~g}$ & 250.33 & 260.40 & 245.20 \\
Antioxidant activity $\%$ & 65.55 & 70.25 & 60.66 \\
\hline
\end{tabular}

Therefore, we showed temperature $60^{\circ} \mathrm{C}$ the best because showed the best result in ascorbic acid, total phenol, $\beta$-carotene, antioxidant activity and viscosity

\section{Physical properties:}

Color Measurement: The color attributes were measured using (Hunter Lab Easy Match QC). For the dried persimmon pulp samples three color parameters ( $a^{*} b^{*}$ and $\left.L^{*}\right)$ were determined. The color of the powder was measured by means of hunter lab $\left(L^{*}, a^{*}\right.$ and $\left.b^{*}\right)$. The $L^{*}$ value represents lightness $\left(L^{*}=\right.$ zero for black, $L^{*}$ $=100$ for white). Whereas the $a^{*}$ scale represents the red/green dimension with positive values for red and negative ones for green. The $b^{*}$ scale represents the yellow/ blue dimensions, with positive values for yellow and negative ones for blue. According to Phoungchandang and Saentaweesuk (2011).

Bulk Density: The bulk density of persimmon pulp powder was determined by filling and empty weighed $100 \mathrm{~cm}^{3}$ glass measuring cylinder with powder sample. The cylinder was shaken for arranging and then re weighed with sample. The bulk density of sample was calculated as the mass /volume relationship $\left(\mathrm{g} / \mathrm{cm}^{3}\right)$ (Zewdu and Solomon 2007).

Water Holding Capacity (WHC): Water holding capacity of persimmon pulp powder was determined following the method described by Ang (1991). By glass rod, a sample of $2 \mathrm{~g}$ was mixed with $30 \mathrm{ml}$ distilled water in $50 \mathrm{ml}$ centrifuge tube. The slurry was allowed to stand for $10 \mathrm{~min}$, and then centrifuge $2.000 \mathrm{xg}$ for 15 min. After centrifugation, the supernatant was drained and the wet sample precipitate was weighed. the result was expressed as $\mathrm{g}$ of water per $\mathrm{g}$ sample.

Oil Holding Capacity (OHC): was measured according to Garau et al. (2007). Samples $(0.2 \mathrm{~g})$ were mixed with sunflower oil $(1.5 \mathrm{~g})$, left overnight at room temperature and then centrifuged (1500 xg; $5 \mathrm{~min}$ ). The supernatant was decanted and the sample was weighed. OHC was evaluated based on the increase in weight and expressed as $\mathrm{g}$ of oil absorbed/g dry sample. 
Emulsifying Properties (EP): The emulsifying capacity was determined as described by Yasumatsu et al. (1972). One g of sample, $15 \mathrm{ml}$ distilled water and $15 \mathrm{ml}$ sunflower oil were prepared in calibrated centrifuged tube. The emulsion was centrifuged at $2000 \mathrm{~g}$ for $5 \mathrm{~min}$. the ratio of the height of emulsion layer to the total height of the mixture was calculated as emulsion capacity in percentage.

Chemical properties: Chemical properties of persimmon (fresh and dried) including moisture content, crude protein, crude fiber and total ash were determined according to the methods of AOAC (2007).

\section{Bioactive component:}

Antioxidant activity: Sample preparation: The extraction of persimmon pulp was carried out using d solvent ethanol $70 \% .2 \mathrm{~g}$ of pulp were mixed with $8 \mathrm{~mL}$ of solvent followed by centrifugation at $10000 \times \mathrm{g}$ for 10 minutes. The supernatant was collected and was used for analysis of antioxidant activity.

DPPH (1,1-dihpenyl-2-picrylhydrazyl) radical scavenging activity: The assay was carried out according to the method of (Akpinar,2010). For DPPH, three different concentrations of persimmon extracts $(0.1,0.2,0.3 \mu \mathrm{L})$ were added to 1.0 $\mathrm{mL}$ of $0.01 \%$ methanolic solution of DPPH. Absorbance at $517 \mathrm{~nm}$ was measured after $30 \mathrm{~min}$. The $\%$ inhibition was calculated against a control using formula as:

$\%$ inhibition $=[$ (A DPPH - A sample) $/ \mathrm{A}$ DPPH $] \times 100$.

Total Phenolics (TP): TP concentrations were assayed using Folin-Ciocalteu method as described by Jayaprakasha et al. (2001). Briefly, in a $10 \mathrm{~mL}$ Eppendorf tube, $7.9 \mathrm{~mL}$ of distilled water, $0.1 \mathrm{~mL}$ of extract, and $0.5 \mathrm{~mL}$ of Folin-Ciocalteu reagent (1:1 with water) were mixed. After $1 \mathrm{~min}, 1.5 \mathrm{~mL}$ of sodium carbonate $(20 \mathrm{~g}$ per $100 \mathrm{~mL}$ ) was added and mixed well. The reaction solution was then incubated at room temperature for $2 \mathrm{~h}$ in the dark before absorbance was read at $765 \mathrm{~nm}$. The TP concentration was calculated from a calibration curve using gallic acid as standard.

Total flavonoid content: Flavonoid content of samples was extracted by $80 \%$ methanol and measured using aluminum chloride according to the method of Olajire and Azeez (2011). Rutin was used as standard and flavonoid contents were measured as $(\mathrm{mg})$ rutin equivalent $(\mathrm{mg} \mathrm{RE} / 100 \mathrm{mg})$. $1 \mathrm{ml}$ of extract was taken into $10 \mathrm{ml}$ volumetric flask, containing $4 \mathrm{ml}$ of distilled water. $0.3 \mathrm{ml}$ of $5 \% \mathrm{NaNO}_{2}$ added to the flask. After $5 \mathrm{~min}, 0.3 \mathrm{ml} 10 \% \mathrm{AlCl}_{3}$ was added to the mixture. At the 6th min, $2 \mathrm{ml}$ of $1 \mathrm{M} \mathrm{NaOH}$ was added and the volume was made up to $10 \mathrm{ml}$ with distilled water. The absorbance was measured spectrophotometrically at $510 \mathrm{~nm}$.

Ascorbic Acid (Vit C): Vitamin C was extracted from the fruits according to the method of Campos et al. (2009). sample was weighed (about $1 \mathrm{~g}$ ) and $15 \mathrm{ml}$ extraction solution ( $3 \%$ metaphosphoric acid, $8 \%$ acetic acid, $0.3 \mathrm{~N}$ sulfuric acid and $1 \mathrm{mM}$ EDTA) was added. Next, the sample was triturated in a microhomogenizer for $5 \mathrm{~min}$ and vacuum filtered through filter paper. The filtrate was 
diluted in ultrapure water until a volume of $25 \mathrm{ml}$ in a volume balloon and centrifuged for $15 \mathrm{~min}$. The supernatant was stored in a refrigerator at about $5{ }^{\circ} \mathrm{C}$ until the time for chromatographic analysis.

The presence of ascorbic acid in fruits was analyzed by HPLC using a Shimadzu liquid chromatography system (model SCL 10AT VP) equipped with a high-pressure pump (model LC-10AT VP), automatic loop injector (50 $\mu \mathrm{l}$; model SIL-10AF), and UV/visible detector (diode array; model SPD-M10A).

$\beta$-carotene content: The $\beta$-carotene content was determined using the modified method of Pinherio Sant Ana et al. (1998). The sample $(1 \mathrm{~g})$ was extracted with a mixture of hexane and acetone $(7: 3,25 \mathrm{ml})$. The extract was filtered through a Buchner funnel with Whatman No. 1 filter paper. The residue was re-extracted until it became colorless. The filtrates were combined in a separator funnel and washed with $50 \mathrm{ml}$ distilled water. The water phase was discarded and $\mathrm{Na}_{2} \mathrm{SO}_{4}$ was added as desiccant. The hexane phase was transferred to a volumetric flask. The concentration of carotene in the solution was determined from the absorbance at $450 \mathrm{~nm}$ (UV-1201; Shimadzu). The $\beta$-carotene content was determined from the standard curve prepared for $\beta$-carotene.

Statistical analysis: Factors considered in the statistical analysis of the data were storage type, storage time and replication. Data analysis was performed using analysis of variance (ANOVA) with the SAS program package (Steel and Torrie, 1980). For the statistical study, randomly selected three samples from each of three replications in any treatments. The means were compared using the least significant difference (LSD) test at $P<0.05$. Sources of variation included storage type and storage time.

\section{RESULTS AND DISCUSSION}

One of the qualities of the parameters of food and agriculture product is the color parameter. Too much color changes influence the marketing negatively by affecting the quality of product. It is an index of the inherent good qualities of a food and the association of color with the acceptability of food is universal (Ismail and Kocabay, 2018).

Color is derived from the natural pigments in fruits and vegetables, many of which change as the plant proceeds through maturation and ripening. The primary pigments imparting color quality are the fat soluble chlorophylls (green) and carotenoids (yellow, orange, and red) and the water soluble anthocyanins (red, blue), flavonoids (yellow), and betalains (red) Altuntas et al. (2011). In addition, enzymatic and non-enzymatic browning reactions may result in the formation of water-soluble brown, gray, and black colored pigments. The enzymes involved in browning reactions include polyphenol oxidase, which catalyzes the oxidation of polyphenolic compounds, and phenylalanine ammonia lyase, which catalyzes the synthesis of precursors to phenolic substrates (Celik and Ercisli, 2008). 
Table (3). Effect of blanching treatment on some physical properties of dried persimmon pulp

\begin{tabular}{ccc}
\hline Properties & \multicolumn{2}{c}{ Value (M \pm SD) } \\
\hline Color & Unblanched dried & Blanched dried \\
$\mathrm{L}^{*}$ & $59.17 \pm 0.06^{\mathrm{b}}$ & $61.55 \pm 0.05^{\mathrm{a}}$ \\
$\mathrm{a}^{*}$ & $1.37 \pm 0.03^{\mathrm{a}}$ & $2.45 \pm 0.04^{\mathrm{b}}$ \\
$\mathrm{b}^{*}$ & $18.85 \pm 0.04^{\mathrm{a}}$ & $19.95 \pm 0.04^{\mathrm{b}}$ \\
\hline
\end{tabular}

The Hunter $\left(L^{*}, a^{*}, b^{*}\right)$ color, $L^{*}$ refers to brightness and $a^{*}$ and $b^{*}$ refer to redness and yellowish of products, respectively. Table (3) showed the effect of blanching on the color which found significant between unblanched and blanched dried pulp. As shown in Table (3), the blanching treatment changed the final dried product lighter, much redder and yellowish. The $\left(\mathrm{L}^{*}\right)$ of unblanched and blanched dried pulp were 59.17 and 61.55 , respectively. The values of $a^{*}$ and $b^{*}$ of unblanched dried pulp were 1.37 and 18.85 , respectively. The blanched treatment increased $a^{*}$ and $b^{*}$ values of blanched dried pulp.

The obtained results were agreed with Marin et al. (2009), who reported that the parameters $a^{*}, b^{*}$ and $L^{*}$ should gain high values to achieve the best dried persimmon product.

\section{Table (4). Effect of blanching treatment on some physical properties of dried persimmon peel}

\begin{tabular}{ccc}
\hline Properties & \multicolumn{2}{c}{ Value( M \pm SD ) } \\
\hline Color & Unblanched dried & Blanched dried \\
$\mathrm{L}^{*}$ & $55.17 \pm 0.06^{\mathrm{b}}$ & $58.55 \pm 0.05^{\mathrm{a}}$ \\
$\mathrm{a}^{*}$ & $3.35 \pm 0.03^{\mathrm{a}}$ & $4.47 \pm 0.04^{\mathrm{b}}$ \\
$\mathrm{b}^{*}$ & $16.75 \pm 0.04^{\mathrm{a}}$ & $17.89 \pm 0.04^{\mathrm{b}}$ \\
\hline
\end{tabular}

Table (4) showed the effect of blanching on the colour of persimmon peel were $55.17,3.35$ and 16.75 for $L^{*}, a^{*}$ and $b^{*}$, respectively. Sakanaka et al. (2005) found $L^{*}, a^{*}$ and $b^{*}$ value of unblanched peel $(45.23,1.23$ and 12.55 , respectively) lower than that found in the present study, Dirim and Caliiskan (2012) recorded lower values of $L^{*}$ and $b^{*}$ parameters beging 40.01,14.78, respectively. On contrast, Guine et al., (2013); Niewczas et al., (2014) and Ismail and Kocaboy (2018) determined values of $L^{*}$ parameter to range from 54.22 to 64.47 , a* parameter ranged from 3.01 to5.23 and $b^{*}$ parameter ranged from 15.45 to 19.65 . Blanched persimmon peel were recorded $58.55,4.47$ and 17.89 for $L^{*}$, $a^{*}$ and $b^{*}$ respectively. Perucho (2015) found $L^{*}, a^{*}$ and $b^{*}$ value of blanched peel lower $(50.24,2.45$ and 14.23 , respectively) than that found in the present study, Dirim and Caliiskan (2012) recorded lower values of $L^{*}$ and $b^{*}$ parameters beging 45.21 and 15.28, respectivily. On contrast, Guine et al. (2013); Niewczas et al. (2014) and Ismail and Kocaboy (2018) determined values of $L^{*}$ parameter to range from 50.14 to 66.32 , a* parameter ranged from 2.23 to 5.27 and $b^{*}$ parameter ranged from 14.36 to 20.25 . 


\section{Physical properties}

Effect of blanching on some physical properties of dried persimmon pulp.

Bulk density is an important consideration in producing persimmon peel and pulp. The result in Table (5) showed increased in blanched dried pulp $(0.59 \mathrm{~g} / \mathrm{ml})$ when unblanched pulp was $(0.52 \mathrm{~g} / \mathrm{ml})$. Bulk density is contingent on particle size distributions and fineness (Saw et al., 2014).

\section{Water-holding capacity (WHC)}

The result showed in Table (5) showed increased water holding capacity in blanched dried pulp was $(85.9 \mathrm{~g} / 100 \mathrm{ml})$ while was $(80.5 \mathrm{~g} / 100 \mathrm{ml})$ in unblanched pulp. The water-holding capacity (WHC) can thus be estimated as the amount of water released from the sample (water retention measurement) or as the amount of water absorbed or bound by the sample (water absorption measurement), Rashead et al. (2015).

\section{Oil holding capacity (OHC)}

Table (5) showed increased oil holding capacity in blanched dried pulp $(95.5 \mathrm{~g} / 100 \mathrm{ml})$ from unblanched dried pulp $(90.6 \mathrm{~g} / 100 \mathrm{ml})$. This result agrees with (Fabeak et al., 2014) while oil holding capacity was in range (80.33 to 98.2 $\mathrm{g} / 100 \mathrm{ml})$.

\section{Emulsifying capacity \% (EC)}

The result showed in Table (5), illustrate that the higher value of emulsifying capacity was blanched dried pulp (35.01\%) followed by unblanched dried pulp was (25. 18\%).It was clear that the blanching treatment had the highest effect on the emulsifying capacity. The effect of blanching treatment on some physical properties of dried persimmon pulp which as important to produce good quality and acceptable sensorial product.

Table (5). Effect of blanching treatment on some physical properties of dried persimmon pulp

\begin{tabular}{lcc}
\hline \multicolumn{1}{c}{ Properties } & \multicolumn{2}{c}{ Value (M \pm SD) } \\
\cline { 2 - 3 } & Unblanched dried & Blanched dried \\
\hline Bulk density $(\mathrm{g} / \mathrm{ml})$ & $0.52^{\mathrm{b}} \pm 0.36$ & $0.59^{\mathrm{a}} \pm 0.50$ \\
Water holding capacity $(\mathrm{g} / 100 \mathrm{ml})(\mathrm{WHC})$ & $80.5^{\mathrm{b}} \pm 5.29$ & $85.9^{\mathrm{b}} \pm 12.9$ \\
Oil holding capacity $(\mathrm{g} / 100 \mathrm{ml})(\mathrm{OHC})$ & $90.6^{\mathrm{b}} \pm 5.98$ & $95.5^{\mathrm{b}} \pm 13.5$ \\
Emulsifying capacity \% $(\mathrm{EC})$ & $25.18^{\mathrm{b}} \pm 0.48$ & $35.01^{\mathrm{b}} \pm 1.09$ \\
\hline
\end{tabular}

Effect of blanching on some physical properties of dried persimmon peel.

The result in Table (6) showed increased in blanched dried peel $(0.45 \mathrm{~g} / \mathrm{ml})$ when unblanched peel was $(0.40 \mathrm{~g} / \mathrm{ml})$. This result agrees with Ramaswamy et al. (2013) which bulk density was range $(0.35$ to $0.50 \mathrm{~g} / 100 \mathrm{ml})$.

\section{Water-holding capacity (WHC)}

The result showed in Table (6) increased water holding capacity in blanched dried peel was $(80.5 \mathrm{~g} / 100 \mathrm{ml})$ while was $(75.6 \mathrm{~g} / 100 \mathrm{ml})$ in unblanched peel. The 
water-holding capacity (WHC) can thus be estimated as the amount of water released from the sample (water retention measurement) or as the amount of water absorbed or bound by the sample (water absorption measurement) (Villemejane et al., 2013).

\section{Oil holding capacity (OHC)}

Table (6) showed increased oil holding capacity in blanched dried peel $(94.3 \mathrm{~g} / 100 \mathrm{ml})$ from unblanched dried peel $(92.6 \mathrm{~g} / 100 \mathrm{ml})$. This result agrees with (Celik and Ercisli, 2009). while oil holding capacity was in range (90.37 to 96.22 $\mathrm{g} / 100 \mathrm{ml})$.

\section{Emulsifying capacity \% (EC)}

The result showed in Table (6), showed the higher value of emulsifying capacity was blanched dried peel $(30.24 \%)$ followed by unblanched dried peel was (22. 36\%).It was clear that the blanching treatment had the highest effect on the emulsifying capacity. The effect by blanching treatment on some physical properties of dried persimmon pulp which as important to produce good quality and acceptable sensorial product (Luo, 2007).

Table (6). Effect of blanching treatment on some physical properties of dried persimmon peel

\begin{tabular}{lcc}
\hline \multirow{2}{*}{ Properties } & \multicolumn{2}{c}{ Value( M \pm SD) } \\
\cline { 2 - 3 } & Unblanched dried & Blanched dried \\
\hline Bulk density $(\mathrm{g} / \mathrm{ml})$ & $0.40^{\mathrm{b}} \pm 0.36$ & $0.45^{\mathrm{a}} \pm 0.50$ \\
Water holding capacity $(\mathrm{g} / 100 \mathrm{ml})(\mathrm{WHC})$ & $75.6^{\mathrm{b}} \pm 5.29$ & $80.5^{\mathrm{b}} \pm 12.9$ \\
Oil holding capacity $(\mathrm{g} / 100 \mathrm{ml})(\mathrm{OHC})$ & $92.6^{\mathrm{b}} \pm 5.98$ & $94.3^{\mathrm{b}} \pm 13.5$ \\
Emulsifying capacity \% $\%(\mathrm{EC})$ & $22.36^{\mathrm{b}} \pm 0.48$ & $30.24^{\mathrm{b}} \pm 1.09$ \\
\hline
\end{tabular}

Table (7). Effect of blanching and drying on chemical properties of soft ripe Persimmon pulp (on dry weight basis)

\begin{tabular}{ccccccc}
\hline \multicolumn{7}{c}{ Composition (g/100g) } \\
\hline Persimmon pulp & Moisture & Protein & Lipid & Ash & Carbohydrate & Fiber \\
\hline Fresh pulp & $8.52 \pm 0.05^{\mathrm{c}}$ & $12.30 \pm 0.02^{\mathrm{a}}$ & $2.35 \pm 0.03^{\mathrm{a}}$ & $8.55 \pm 0.05^{\mathrm{a}}$ & $60.00 \pm 0.54^{\mathrm{a}}$ & $8.28 \pm 0.05^{\mathrm{a}}$ \\
Unblanched dried pulp & $8.30 \pm 0.05^{\mathrm{b}}$ & $12.0 \pm 0.02^{\mathrm{cd}}$ & $2.20 \pm 0.02^{\mathrm{c}}$ & $8.20 \pm 0.04^{\mathrm{a}}$ & $61.30 \pm 0.17^{\mathrm{c}}$ & $8.00 \pm 0.05^{\mathrm{b}}$ \\
Blanched dried pulp & $8.50 \pm 0.05^{\mathrm{c}}$ & $12.33 \pm 0.09^{\mathrm{e}}$ & $2.30 \pm 0.34^{\mathrm{d}}$ & $6.57 \pm 0.05^{\mathrm{c}}$ & $62.00 \pm 0.18^{\mathrm{b}}$ & $8.30 \pm 0.05^{\mathrm{b}}$ \\
\hline${ }^{*}$ pulp dried at $60^{\mathrm{C}} \mathrm{c}$ for 48 hours, blanching on $90^{\circ} \mathrm{c}$ for 1 min & & &
\end{tabular}

The blanching is very important parameter that affects the drying time. The blanched samples were found to have a shorter drying time compared to the control samples. The drying time required to reach final water content $20 \pm 0.5 \%$ for blanched samples. The drying time was reduced by about $21-42.8 \%$ for persimmon slices, as drying temperature was raised from 50 to $80 \mathrm{C}$. Similar findings were reported in drying of various agricultural products. The chemical properties of fresh persimmon pulp treated under different process conditions are presented in Table (7). The moisture, protein, lipid, ash, carbohydrate and fiber 
contents in fresh pulp were $8.52,12.30,2.35,8.55,60.00$ and $8.28 \mathrm{~g} / 100 \mathrm{~g}$ on dry weight basis, respectively. Slight increases in contents of those examined components were observed after blanching pretreatment and drying processes.

The moisture, protein, lipid, ash, carbohydrate and fiber contents of dried unblanched increased from $8.30,12.00,2.20,61.30$ and 8.00 to $8.50,12.33,2.30$, $6.57,62.00$ and $8.30 \mathrm{~g} / 100 \mathrm{~g}$ dry weight basis for dried blanched pulp, respectively.

This means that blanching treatment was effective. These results were similar to those as reported by Matsumoto et al. (2010). They found that blanching and salt and sugar solution were more effective than the control fruit.

The moisture content and water activity are considered indices of quality control for dried food processing and preservation. Moisture content and water activity of dried persimmon. The moisture content of dried persimmon was evaluated following blanching treatment (Table 7). The water content was the highest for fresh pulp (8.52\%) while was (8.30 and $8.50 \%)$ in unblanched dried pulp and blanched dried pulp, respectively. The water content increased as compared to the other, while the control showed relatively lower moisture content as compared the other, Mala and Kurian (2016).

The content of carbohydrate determines the sweetness of persimmons, which is very important for the overall organoleptic appearance of the fruit. Among the investigated sugars, glucose was the predominant representative at both commercial harvest and physiological ripening stage in all investigated cultivars.

\section{Table (8). Effect of blanching and drying on chemical properties of soft ripe Persimmon peel (on dry weight basis)}

\begin{tabular}{ccccccc}
\hline \multicolumn{7}{c}{ Composition (g/100g) } \\
\hline Persimmon peel & Moisture & Protein & Lipid & Ash & Carbohydrate & Fiber \\
Fresh peel & $8.55 \pm 0.05^{\mathrm{c}}$ & $10.22 \pm 0.02^{\mathrm{a}}$ & $6.54 \pm 0.14^{\mathrm{a}}$ & $3.35 \pm 0.03^{\mathrm{a}}$ & $62.89 \pm 0.54^{\mathrm{a}}$ & $8.45 \pm 0.05^{\mathrm{a}}$ \\
Unblanched dried peel & $5.70 \pm 0.01^{\mathrm{b}}$ & $10.95 \pm 0.02^{\mathrm{cd}}$ & $6.90 \pm 0.02^{\mathrm{c}}$ & $3.30 \pm 0.25^{\mathrm{a}}$ & $64.40 \pm 0.17^{\mathrm{c}}$ & $8.75 \pm 0.04^{\mathrm{b}}$ \\
Blanched dried peel & $5.98 \pm 0.05^{\mathrm{c}}$ & $11.21 \pm 0.09^{\mathrm{e}}$ & $3.44 \pm 0.34^{\mathrm{d}}$ & $3.55 \pm 0.03^{\mathrm{c}}$ & $66.94 \pm 0.18^{\mathrm{b}}$ & $8.89 \pm 0.05^{\mathrm{b}}$ \\
\hline${ }^{*}$ peel dried at $60^{\circ}$ for 48 hours, blanching on $90^{\circ} \mathrm{c}$ for $1 \mathrm{~min}$ & & & &
\end{tabular}

${ }^{*}$ peel dried at $60^{\circ} \mathrm{c}$ for 48 hours, blanching on $90^{\circ} \mathrm{c}$ for $1 \mathrm{~min}$

The chemical properties of ripe soft persimmon peels treated with different process conditions are presented in Table (8). The chemical properties of moisture contents in persimmon peel, ash, fat, crude protein and carbohydrate contents were recorded in grams per $100 \mathrm{~g}$ of dry material samples except for moisture content. Moisture value was significantly in fresh peel $(8.55 \mathrm{~g} / 100 \mathrm{~g})$ than the others $(5.70-5.98 \mathrm{~g} / 100 \mathrm{~g})$. These values are similar to those found by Park et al. (2008) where they reported that moisture was 8.55 and $5.98 \mathrm{~g} / 100 \mathrm{~g}$, respectively. 
The ash content showed $3.35,3.30$ and $3.55 \mathrm{~g} / 100 \mathrm{~g}$ for fresh peel, unblanched dried peel and blanched dried peel, respectively. While crude protein was higher than of blanched dried peel from fresh and unblanched 11.21,10.22 and $10.95 \mathrm{~g} / 100 \mathrm{~g}$, respectively. Carbohydrate contents was $62.89,64.40$ and $66.94 \mathrm{~g} / 100 \mathrm{~g}$ of fresh peel, unblanched and blanched peel respectively, which the highest was the blanched dried peel. The fiber content in Table (8) were 8.45, 8.75 and $8.89 \mathrm{~g} / 100 \mathrm{~g}$ for fresh peel, unblanched dried peel and blanched dried peel respectively, it was clear that blanched dried peel has the highest value.

Table (9). Effect of blanching on bioactive component of soft ripe persimmon pulp

\begin{tabular}{ccccc}
\hline Parameters & \multicolumn{4}{c}{ Bioactive component } \\
\hline Persimmon pulp & $\begin{array}{c}\text { Ascorbic acid } \\
\mathbf{~ m g / 1 0 0 g}\end{array}$ & $\begin{array}{c}\text { Total phenol } \\
\text { mg/100g }\end{array}$ & $\begin{array}{c}\boldsymbol{\beta} \text { - carotene } \\
\text { mg/100g }\end{array}$ & $\begin{array}{c}\text { Antioxidant } \\
\text { activity \% }\end{array}$ \\
\hline Fresh pulp & $200.21 \pm 0.72^{\mathrm{c}}$ & $230.28 \pm 0.85^{\mathrm{a}}$ & $290.55 \pm 0.95^{\mathrm{b}}$ & $65.80 \pm 0.24^{\mathrm{c}}$ \\
Unblanched dried pulp & $150.80 \pm 0.11^{\mathrm{b}}$ & $245.20 \pm 0.28^{\mathrm{a}}$ & $305.90 \pm 2.29^{\mathrm{c}}$ & $70.30 \pm 0.27^{\mathrm{d}}$ \\
Blanched dried pulp & $180.33 \pm 0.23^{\mathrm{b}}$ & $250.50 \pm 0.38^{\mathrm{a}}$ & $320.22 \pm 1.97^{\mathrm{c}}$ & $75.25 \pm 0.30^{\mathrm{d}}$ \\
\hline
\end{tabular}

${ }^{*}$ pulp dried at $60^{\circ} \mathrm{C}$ for 48 hours, blanched on $90^{\circ} \mathrm{C}$ for $1 \mathrm{~min}$

Data expressed, on a dry weight basis, as mean \pm standard deviation of three determinations. Means followed by different uppercase superscript letters in each column are significantly different $(P<0.05)$.

Table (9) shows the effect of blanching on bioactive component in soft ripe persimmon pulp. It was clear that ascorbic acid decreased from $200.21 \mathrm{mg} / 100 \mathrm{~g}$ to 180.80 and $150.33 \mathrm{mg} / 100 \mathrm{~g}$ for unblanched and blanched dried pulp respectively. The result showed that total polyphenol in Table (9) was 230.28, 245.20 and $250.50 \mathrm{mg} / 100 \mathrm{~g}$ for fresh, unblanched dried pulp and blanched dried persimmon, respectively. The content of the total polyphenols in blanched dried persimmon was higher than unblanched dried pulp and fresh pulp was comparable. Polyphenols are secondary metabolites of plants and are generally involved in defense against ultraviolet radiation or aggression by pathogens. In food, poly phenols may contribute to bitterness, astringency, color, flavor, odor and oxidativestability. Polyphenols are of interest because of their potential use as prophylactic and therapeutic agents in the treatment of many diseases, and much work has been presented by the scientific community which focuses on their antioxidant effects. Plant polyphenols have been studied with the intention of finding compounds which protect against a number of diseases related to oxidative stress and free radical-induced damage, such as cardiovascular and neurodegenerative diseases, cancer, diabetes, auto immune disorders and some inflammatory diseases (Shofian et al., 2012).

Carotenoids are pigmented compounds abundant in fruits and vegetables have yellow, orange and red color. They usually exist as $\alpha, \beta$ and $\gamma$-forms with specific biological activities. Persimmon is rich in carotenoids especially $\beta$ carotenes that can be converted to $\beta$-cryptoxanthin. Both these component possesses substantial biological activities (Sarkar et al., 1995; Kumazawa et al., 
2014). Various scientists (Sakanaka et al., 2005; Zou et al., 2012) already reported that $\beta$ carotenes are predominant in the persimmon fruit followed by $\beta$-cryptoxanthin and acarotenes. The content of $\beta$ - carotene was $290.55,305.90$ and 320.22 $\mathrm{mg} / 100 \mathrm{~g}$ for fresh, unblanched dried pulp and blanched dried persimmon, respectively. The content of the $\beta$-carotene in blanched dried persimmon was higher than unblanched dried pulp and fresh pulp.

The result of antioxidant activity in Table (9) was clear that $65.80,70.30$ and $75.25 \%$ for fresh, unblanched dried pulp and blanched dried persimmon, respectively. The content of the antioxidant activity in blanched dried persimmon was higher than unblanched dried pulp and fresh pulp. Our results compared favorably with previous studies on Diospyros kaki L. (Sharma et al., 2013), and showed similar antioxidant activity. Zdunic et al. (2016) reported that the antioxidant activity of blanched dried pulp was higher than unblanched dried pulp.

The result in Table (9) found decrease in ascorbic acid in blanched dried pulp because effect blanching and solubility of ascorbic in water while total phenol increased in blanched dried pulp because blanching inhibition of enzymes and it happened increased in $\beta$-carotene in blanched dried pulp as a result increased antioxidant activity in blanched dried pulp and this result agree with (Jaerger et al., 2014). The antioxidant activities and total phenolic contents of fruit were studied. The results showed that all fruit extracts exhibited strong antioxidant activities, which correlated positively with the total phenol contents. This study demonstrates the fruits of Diospyros kaki, as possible source of valuable polyphenol content with high antioxidant activities and health-promoting properties.

\section{Table (10). Effect of blanching on bioactive component of soft ripe persimmon peel}

\begin{tabular}{ccccc}
\hline Parameters & \multicolumn{3}{c}{ Bioactive component } \\
\hline Persimmon peel & $\begin{array}{c}\text { Ascorbic acid } \\
\mathbf{~ m g / 1 0 0 g}\end{array}$ & $\begin{array}{c}\text { Total phenol } \\
\mathbf{~ m g / 1 0 0 g}\end{array}$ & $\begin{array}{c}\boldsymbol{\beta} \text { - carotene } \\
\mathbf{m g} / \mathbf{1 0 0 g}\end{array}$ & $\begin{array}{c}\text { Antioxidant } \\
\text { activity \% }\end{array}$ \\
\hline Fresh peel & $188.21 \pm 0.72^{\mathrm{c}}$ & $200.28 \pm 0.85^{\mathrm{a}}$ & $285.55 \pm 0.95^{\mathrm{b}}$ & $68.80 \pm 0.24^{\mathrm{c}}$ \\
Unblanched dried peel & $155.22 \pm 0.11^{\mathrm{b}}$ & $230.20 \pm 0.28^{\mathrm{a}}$ & $300.90 \pm 2.29^{\mathrm{c}}$ & $75.30 \pm 0.27^{\mathrm{d}}$ \\
Blanched dried peel & $175.30 \pm 0.23^{\mathrm{b}}$ & $245.50 \pm 0.38^{\mathrm{a}}$ & $340.22 \pm 1.97^{\mathrm{c}}$ & $77.25 \pm 0.30^{\mathrm{d}}$ \\
\hline
\end{tabular}

${ }^{*}$ peel dried at $60^{\circ} \mathrm{C}$ for 48 hours, blanched on $90^{\circ} \mathrm{c}$ for $1 \mathrm{~min}$

The blanching is very important parameter that affects the drying time. The blanched samples were found to have a shorter drying time compared to the control samples (Martínez-Las. et al., 2014). According to Fennema (1977), ascorbic acid is considered as an index of nutrient quality during processing and storage of foods, and that's why we examined the content of vitamin $C$ in fresh and in all variant of pre-treated dried persimmon. The result showed in Table (10) the content of vitamin C in fresh persimmon fruit was in the range on $188.21 \mathrm{mg} / 100$ g. In dried peel unblanched persimmon fruit the content of vitamin $C$ was in the range on $175.22 \mathrm{mg} / 100 \mathrm{~g}$ on dry weight basis and was $155.30 \mathrm{mg} / 100 \mathrm{~g}$ on dry weight basis in blanched dried peel. Generally, persimmon fruit is a good source 
of ascorbic acid (vitamin C) and also for carotene (pro vitamin A). The contents of all analyzed parameters were lower than in blanched dried peel compared to unblanched dried peel.

The content of total phenol was $200.28,230.20$ and $245.50 \mathrm{mg} / 100 \mathrm{~g}$ for fresh, unblanched dried peel and blanched dried peel persimmon, respectively. The content of the total polyphenols in fresh and equivalent quantities of dried persimmon was comparable $(P<0.05)$. The content of $\beta$-carotene was 285.55, 300.90 and $340 \mathrm{mg} / 100 \mathrm{~g}$ for fresh, unblanched dried peel and blanched dried peel persimmon, respectively. The content of $\beta$-carotene in fresh was lower than unblanched dried persimmon and blanched dried peel. The content of antioxidant activity was $68.80,75.30$ and $77.25 \%$ for fresh, unblanched dried peel and blanched dried peel persimmon, respectively. The content of antioxidant activity in fresh peel was lower than unblanched dried persimmon and blanched dried peel.

The result in Table (10) decrease in ascorbic acid in blanched dried peel because effect blanching and solubility of ascorbic in water while total phenol increased in blanched dried peel because blanching inhibition of enzymes and it happened increased in $\beta$-carotene in blanched dried peel as a result increased antioxidant activity in blanched dried pulp and this result agree with (Gorinstein et al.,2001), The antioxidant activities and total phenolic contents of fruit were studied. The results showed that all fruit extracts exhibited strong antioxidant activities, which correlated positively with the total phenol contents. This study demonstrates the fruits of Diospyros kaki, as possible source of valuable polyphenol content with high antioxidant activities and health-promoting properties.

\section{REFERENCES}

Akpinar EK. Drying of mint leaves in a solar dryer and under open sun: Modelling, performance analyses. Energy Convers Manage 51:2407-18

Akyıldız A, Aksay S, Benli H, Kıroğlu F and Fenercioğlu H (2004). Determination of changes in some characteristics of persimmonduring dehydration at different temperatures. J Food Eng, 65:95-99.

Altuntas E, Cangi R, Kaya C. (2011). Physical and chemical properties of persimmon fruit. Int.; 25:89-92.

Ang,J.F.(1991).Water retention capacity and viscosity effect of powdered cellulose. Journal of Food science, 56(6):1682-1684.

AOAC (2007). Association of Official Analytical Chemists. AOAC International. $\left(18^{\text {th }}\right.$ ed). Gaitherburg: Maryland, USA.

Bubba, M. D., Giordani, E., Pippucci, L., Cincinelli, A., Checchini, L. and P. Galvan, (2009). Changes in tannins, ascorbic acid, and sugar content in astringent persimmons during on-tree growth and ripening and in response to different postharvest treatments. J. Food Compos. Anal., 22: 668-677.

Campos, F, M., Ribeiro, S. M. R., Della Lucia, C. M., Penheiro Sant Anta, H. M., and Stringeta, P.C. (2009). Optimization of methodology to analyze 
ascorbic and deyhyderoascorbic acid in vegetables, Quamica Nova,32(1):78-91.

Celik A, Ercisli S. (2008). Persimmon cv. Hachiya (Diosyros Kaki Thunb.) Fruit: Some Physical, Chemical and Nutrional Properties. Int. J Food Sci. Nutr., 59:599606.

Celik A. and Ercisli S. (2009). Some physical properties of pomegranate cv. Eksinar. Int. Agrophysics, 23, 295-298.

Dirim,S.M. and Caliskan, G.(2012). Determination of the effect of freeze drying process on the production of persimmon powder properties. GIDA,37(4):203-21.

Fabek, H., Messerschmidt, S., Brulport, V., Goff, H. D. (2014). The effect of in vitro digestive processes on the viscosity of dietary fibers and their influence on glucose diffusion. Food Hydrocoll., 35: 718-726.

Fennema, OR. (1977). Loss of vitamins in fresh and frozen foods. Food Technol, $31: 32$.

Garau, MC, Simul, S., Rossello, C. and Femenia, A. (2007). Effect of air-drying temperature on physico-chemical properties of dietary fiber and antioxidant capacity of orange (Citrus aurantium v. Canoneta) by-products. Food Chem, 104:1014-1024.

Galeazzi, M.M., Sgarbieri C.V. and Constantinides M.S. (1981). Isolation purification and physicochemical characterization of polyphenoloxidase (ppo)from a Dwart variety of bana.J.Food Sci.,46:150-155.

Gorinstein, S., Zachwieja, Z., Folta, M., Barton, H., Piotrowicz, J., Zemser, M., Weisz, M., Trakhtenberg, S.., Ma'rtı'nBelloso O. (2001). Comparative content of dietary fiber, total phenolics and minerals in persimmon and apples. J Agric Food Chem, 49:952/957.

Guine,R.P.F., Pinho, S. and Barroca, M.J.(2013). Study of the convective dryied of persimmon. Food and Bioproducts proproducts processing,89:422-824.

Hafez, O.M., Hamouda, H.A. and Abd-El-Mageed, M.A. (2010). Effect of calcium and some antioxidants treatments on storability of Le Conte pear fruits and its volatile components. Selcuk Tarim Bilimleri Dergisi, 24: 87-100.

Hazbavi, E., Minaei, S. (2010). Making and investigation quality properties of dried persimmon slice. Journal of Food Science and Technology, 7: 65-72.

Ismail,O and Kocabay, O.G.(2018).Evaluation drying methods and conditions with respt to drying kinetics, color quality and specific energy consumption of thin layer persimmon Bulgarian Chemical Communications,48(3):480-491.

Itamura, H, Zheng Q, Akaura K. (2005). Industry and research trend of Japanese persimmon. Acta Horticult, 685:37-44.

Jaeger de Carvalho, J. L.V., Cardoso, F.S.N. and Koblitiz, M. J. B. (2014). Assessment of carotenoids in persimmon after different conditions. Food Science and Technology, 34(2):365-370.

Jayaprakasha, GK., Singh, RP., Sakariah, KK. (2001). Antioxidant activity of grape seed (Vitis vinifera) extracts on peroxidation models in vitro. Food Chemistry, 73:285-290. 
Jung, ST, Park, YS, Zachwieja, Z, Folta, M, Barton, H, Piotrowicz, J, (2005). Some essential phytochemicals and the antioxidant potential in fresh and dried persimmon. Int J Food Sci Nutr., 56:105-13.

Kim, C. J., Shu, H. J., and Chung, H. S. (2016). Evaluation of antimicrobial activities of Rhubarb extracts on putrefactive microorganisms related to soybean curd (Doobu). Journal of the Korean Society of Dietary Culture, 21, 225-231.

Kondo, S., Yoshikawa, H. and R. Katayama, (2004). Antioxidant activity in astringent and non-astringent persimmons. J. Hortic. Sci. Biotechnol., 79 (3): 390-394.

Kulaitiene,J., Jariene,E., Danilcenko, H., Cerniauskiene, J., Wawrzynia, Hamulka, J. and Jukneviciene,E.(2014). Chemical compostion of persimmon flesh used a food Agriculture and Enviromental, 12(3,4):61-64.

Larrauri, J.A. (1999). New approaches in the preparation of high dietary fiber from fruit by-products. Trends Food Sci Tech, 10:3-8.

Lo'ay, A.A., (2010). Cyanocobalamin control fruit ripening of persimmon fruits. Journal of Plant Production, 1: 1653 - 1663.

Liu H.F., Zhang J.G., Guo L.P. (2007). Study on technology of storage and freshkeeping of 'Mopan' persimmon. Tianjin Science and Technology in Agriculture and Forestry, 15: 1-23.

Luo, Z. (2007). Effect of 1-methylcyclopropene on ripening of postharvest persimmon (Diospyros kaki L.) fruit. LWT Food Sci Techno., 40:285-91.

Mala,K. S. and Kurian, A.E. (2016).Nutritional compostion and antioxidant activity of persimmon wastes. Internatonal Journal of pharmaceutical, chemical and biological sciences,6(3):336-334.

Marin, F.R., Soler-Rivas, C., Benavente-Garcia, O., Castillo, J. and PerezAlvarez, J.A. (2009). By-products from different citrus processes as a source of customized functional fibers. Food Chem, 100:736-741.

Martínez-Las, H.R, Heredia, A., Castelló, M.L., Andrés, A.(2014). Influence of drying method and extraction variables on the antioxidant properties of persimmon leaves. Food Biosci, 6:1-8. doi: 10.1016/j.fbio.2014.01.002.

Mangarova, M., (2011). Chemical contents of persimmon fruits (Diospyros kaki), grown in the conditions of the southern Black sea region. Plant Sci., 42: 443 $-445(\mathrm{Bg})$.

Matsumoto, K., Yokoyama, S. and N. Gato, (2010). Bile acid-binding activity of young persimmon (Diospyros kaki) fruit and its hypolipidemic effect in mice. Phytother. Res., 24: 205-210.

Niewczas, J., Mitek, M., Korzeniewska, A. and Niemirowicz-Szcytt, K. (2014). Characteristics of selected quality trats of novel cultivars of persimmon (Cucurbita Maxima Duch.). Polish journal of Food and Nutrition Sciences, 64(2):101-107.

Novillo, P., A. Salvador, E. Llorca, I. Hernando and Besada, C. (2014). Effect of $\mathrm{CO}_{2}$ deastringency treatment on flesh disorders induced by mechanical damage in persimmon. Biochemical and microstructural studies. Food Chem., 145: 454-463. 
Novillo, P., C. Besada, L. Tian, A. Bermejo and Salvador, A. (2015). Nutritional composition of ten persimmon cultivars in the "ready-to-eat crisp" stage. Food Nutr. Sci., 6: 1296-1306.

Olajire, A.A. and Azeez, L. (2011). Total antioxidant activity, phenolic, flavonoid and ascorbic acid contents of Nigerian vegetables. Africa Journal of Food Science and Technology,2:22-29.

Özdemir, A.E., Çandır, E.E., Toplu, C., Kaplankıran, M., Yıldız, E., Inan, C. (2009). The effects of hot water treatments on chilling injury and cold storage of fuyu persimmons. African Journal of Agricultural Research, 4 :1058-1063.

Park, Y.-S., Leontowicz, H., Leontowicz, M., Namiesnik, J., Jesion, I. and Gorinstein,S. (2008). Nutraceutical value of persimmon (Diospyros kaki Thunb.) and its influence on some indices of atherosclerosis in an experiment on rats fed cholesterolcontaining diet. Adv. Hort. Sci., 22 (4): 250-254.

Perucho, R. (2015). Antecedentes e importancia económica. In: Badenes, L., Intrigliolo, D., Salvador, A., Vicent, A., (Eds.), El cultivo del caqui. Valencia (pp.18-34). Valencia: Generalitat Valenciana.

Penheiro Sant Anta, H. M., and Stringeta, P.C. Brandao.S.C.C., and Azeredo, R.M.C. (1998). Carorenoid retention and vitamin A value in carrot (Dauacus Carota L) Prepared by Food Service. Food Chemistry, 61(1-2):145-151.

Phoungchandang, S. and Saentaweesuk, S. (2011). Effect of two stage tray and heat pump assisted - dehumidified drying on drying characteristics and qualities of dried ginger. Food and Bioproducts Processing, 89(4):429-437.

Ramaswamy, U. R., Kabel, M. A., Schols, H. A., Gruppen, H. (2013). Structural features and water holding capacities of pressed potato fiber polysaccharides. Carbohydr. Polym., 93: 589-596.

Rashid, S., Rakha, A., Anjum, F. M., Ahmed, W., Sohail, W. (2015). Effects of extrusion cooking on the dietary fi bre content and Water Solubility Index of wheat bran extrudates. Int. J. Food Sci. Technol., 50:1533-1537.

Sakanaka, S, Tachibana Y, Okada Y. (2005). Preparation and antioxidant properties of extracts of Japanese persimmon leaf tea (kakinoha-cha). Food Chem., 89:569-75.

Sarkar A, Bishayee A, Chatterjee M. (1995). Beta-carotene prevents lipid peroxidation and red blood cell membrane protein damage in experimental hepatocarcinogenesis. Cancer Biochem Biophys, 15:111-25.

Salvador, A., Arnal, L., Besada, C., Larrea, V., Quiles, A. and I. PerezMunuera, (2007). Physiological and structural changes during ripening and deastringency treatment of persimmon fruit cv. 'Rojo Brillante'. Postharvest Biol. Tec., 46: 181-188.

Saw, H. Y., Davies, C. E., Jones, J. R., \& Paterson, A. H. J. (2014). Shear testing of lactose powders: The influence of consolidation stress and particle size on bulk density and estimated cohesion, Conference paper. Advances in Powder Technology, 25: 1164-1170. 
Senter, S. D., Chapman, G. W., Forbus, W. R., Payne, J. R. and J. A. Payne, (1991). Sugar and non-volatile acid composition of persimmons during maturation. J. Food Sci., 56: 989-991.

Sharma, S.K., Chaudhary, S.P., Rao, V.K., Yadav,V.K. and Bisht,T. S.( 2013). Standardization of technology for preparation and storage of wild apricot fruit bar. J. Food Sci. Technol., 50: 784-790.

Steel, R.B.D. and Torrie, T. H. (1980). Principles and procedures of statistics. USA:MS GRAW Hill Co.

Sultan, M., Ibrahim, S., Hafez, O.M. and Saleh, M.A. (2016). Cellulose sulfate active packaging material with treatments on orange shelf life. Int. J. Pharm Tech Res., 9: 79-90.

Villemejane, C., Roussel, P., Berland, S., Aymard, P., Michon, C. (2013). Technological and sensory tools to characterize the consistency and performance of breen riched biscuit doughs. J. Cereal Sci., 57, 551-559.

Yasumatsu, K., Sawada, K., Moritaka, S., Misaki, M., Toda, J., Wada, T. and Ishii, K. (1972). Whipping and emulsifying properties of soybean products. Agricultural and Biological Chemistry, 36(5):719-727.

Yokozawa, T., Kim, Y.A, Kim, H.Y., Lee, Y.A., Nonaka, G. (2007). Protective effect of persimmon peels polyphenol against high glucose-induced oxidative stress in LLCPK1 cells. Food Chem Toxicol, 45:1979-87.

Yordanov, A. (2011). Chemical composition of persimmon fruits (Diospyros kaki L.) at commercial harvest and physiological ripening stage. Plant Sci., 48: 134-137 (Bg).

Zdunic, G.M., Menkovic,N.R., Jadranin,M.B.,Novakvic, M.M., Savikin,K.P. and Zivkovic, J.C. (2016).Phenolic compounds and carotenoids in persimmon fruit and related traditional Assessment of carotenoids in persimmon after diffonal products. Hemijska inustrija, 70(4):429-433.

Zewdu A.D. and Solomon, W.K. (2007). Moisture dependent physical properties of seed. Biosystems Engineering, 96: 57-63.

Zou, B, L., Chen, J.Y, Dong, X.Q, Zhang,Y. and Du, J. (2012). High molecular weight persimmon tannin is a potent hypolipidemic in high-cholesterol diet fed rats. Food Res Int. 2012; 48:970-7. 


\title{
الملخص العربي \\ تأثير بعض المعاملات الأولية قبل التجفيف علي الخواص الطبيعية والمكونات الحيوية النشطة لثمار الكاكي الناضجة المجففة
}

\author{
داليا عياد قلينى عوض' , (يمن ابو اليزيل' , سلوى دانيال ', هانم محمد عثمان '

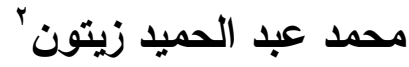 \\ 'قسم بحوث الحاصلات البستانية - معهد بحوث تكنولوجيا الاغذية - مركز البحوث الزراعية - مصر \\ كَسم علوم الاغذية - كلية الزراعة - سابا باشا - جامعة الاسكندرية
}

تعتبر ثمار الكاكي واحدة من الاغذية الني تعزز الصحة باعتبارها واحدة من الفواكه الرئيسية التي تحتوى على مركبات

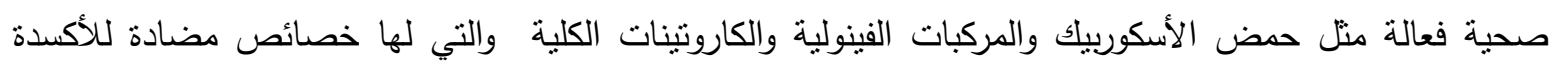
ومعززة للصحة .وكان الهدف من هذا البحث هو تقييم جودة القشر واللب المجفف من خلال عملية السلق وتم تقدير ذللك من خلال تحديد الخواص الفيزيائية ، التركيب الكيميائي و بعض المكونات النشطة حيويا والمضادة للأكسدة في هي هندي كل من لب الثمرة وقشرتها ـ ولتحقيق هذا الهذف نم فرز وتدريج وغسيل ثمار الكاكي وتم معاملة السلق لتنبيط الانزيمات اثثاء عملية التجفيف ثم تقدير الخواص الطبيعية والكيميائية والمكونات النشطة حيويا وذلك بتقدير تأثنير معاملات السلق على كل من لب وقثرة الثمار المجففة وكان من اهم النتائج التي تم الحصول عليها اختبارات اللون

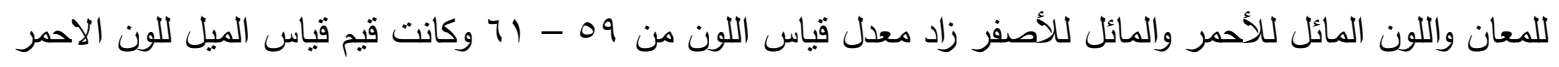

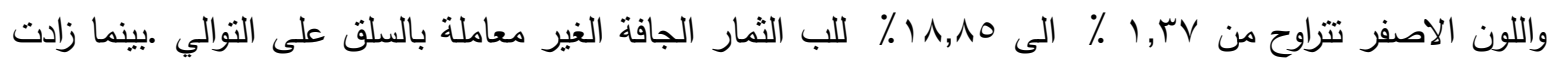
قيم قياس اللون المائل للون الاحمر والمائل للون الاصفر للب الثمار المجفة المعاملة بالسلق لذلك كان تأثير معاملة

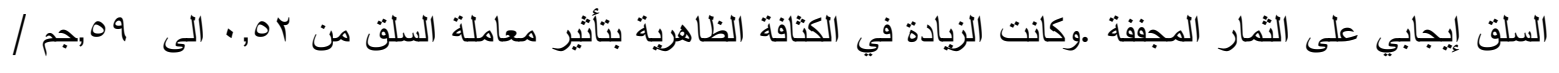

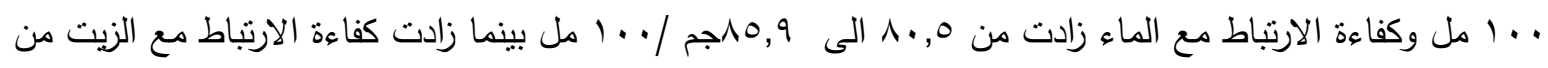

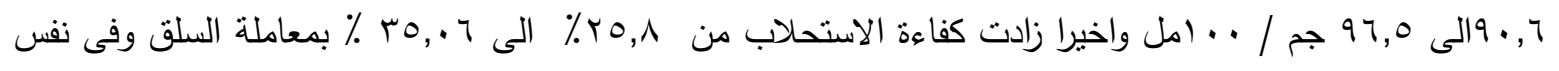
الوقت ادت معاملات السلق الى زيادة طفيفة في كل من لب الثمار والقشرة للرطوبة والبروتين والدهون والرماد والكربوهيدرات والالياف .ادت معاملة السلق الى انخفاض معدل حامض الاسكوربيك في لب الثمار المجفة حيث كان

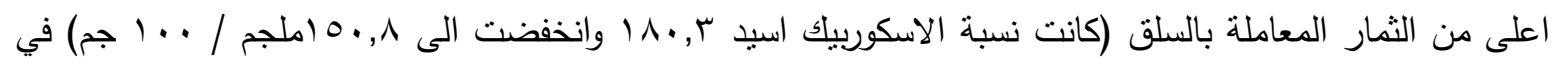

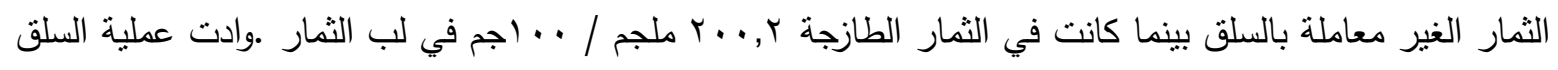
(معاملات السلق) الى زيادة المركبات الفينولية الكلية والبيتا كاروتين وفى نفس الوقت ادى ذلئه ذلك الى زيادة نسبة نشاط

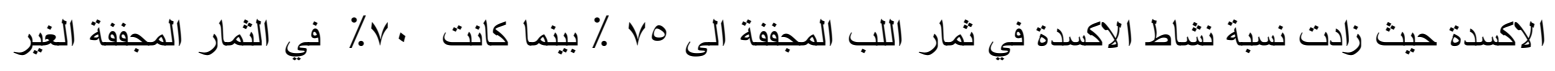
معاملة بالسلق واخيرا ادت معاملات السلق الى نفس الاتجاه لقيم المكونات الفعالة حيويا لكل من الاسكوربيك والمركبات

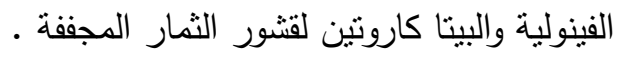


